\title{
高知県東洋町における高レベル放射性廃棄物 処分地決定に係る紛争の対立要因と解決策
}

\author{
DECISIVE FACTORS OF THE DISPUTE REGARDING HIGH-LEVEL \\ RADIOACTIVE WASTE REPOSITORY SITING AT TOYO-CHO, KOCHI, JAPAN: \\ AN ANALYSIS OF POLITICAL PROCESS AND POSSIBLE SOLUTIONS
}

\author{
西郷 貴洋 ${ }^{1}$ ・ 小松崎 俊作 ${ }^{2} \cdot$ 堀井 秀之 ${ }^{3}$

\begin{abstract}
1 修士（工学） (株三菱総合研究所 科学・安全政策研究本部 (E-mail: saigo@mri.co.jp) ${ }^{2}$ M.A. (政策科学) 東京大学大学院工学系研究科 特任研究員 (E-mail: komatsuzaki@civil.t.u-tokyo.ac.jp)
\end{abstract} \\ ${ }^{3} \mathrm{Ph} . D$. (社会技術論) 東京大学大学院工学系研究科＼cjkstart教授 (E-mail: horii@civil.t.u-tokyo.co.jp)
}

\begin{abstract}
2006 年から 2007 年にかけて高知県東洋町で発生した高レベル放射性廃棄物（HLW）処分地候補の文献 調查への応募を巡る紛争においては，住民間で激しい対立が起きて冷静な議論ができず，町内に禍根を残 した. 本研究では今後の処分地選定においても懸念される対立の緩和に資する教訓を得るため, 東洋町で の紛争の政治過程分析・対立要因の抽出・解決策の導出・解決策のシナリオ分析を行った. その結果，公 募に基づく当時の HLW 処分地選定制度に起因し, 住民の対立感情や住民間の禍根といった問題の解決を困 難にしている要因の一つとして，「自ら応募し，交付金を受け取るという構図」の存在により，金目当ての 応募であるという批判に反論できないという要因を抽出した.
\end{abstract}

キーワード : 高レベル放射性廃棄物処分地選定, 政治過程, シナリオ分析, 対立要因の抽出, 高知県東洋町

\section{1. 研究の背景及び目的}

2007 年 1 月，高レベル放射性廃棄物(HLW)処分場立地 のための文献調査に，高知県東洋町がわが国で初めて応 募した. 署名活動等の反対運動や，06 年 3 月付けで提出 された応募書が暴露されるなどの混乱の中の応募であっ た. その後さらに町内は混乱，4 月には応募を主導した 町長が辞職し，選挙を経て応募反対の立場をとる新町長 が誕生，応募を取り下げるという結末をみた。この一連 の過程では推進派・反対派の激しい対立が起き, 冷静に 賛否を議論できず, 町内に禍根を残した. 今後, 他の地 域で応募・立地が問題になった場合も同様の対立が起こ ることが懸念されるため，対立の緩和に資する教訓を本 事例から得るべきである.

本研究ではこの問題意識から, 東洋町における HLW 処分地決定に係る紛争の政治過程を明らかにしたのち, 公募による HLW 処分地決定プロセスに存在する解決困 難な対立要因を抽出することを目的とした.

\section{2. 先行研究 $\cdot$ 方法}

本研究のようにコンフリクト事例を記述・分析する研
究は, 政治学においては「政策過程分析」の分野で盛ん に行われてきた。 また，社会学においても，政治過程と いう語は用いないが，類似する事例を記述・分析する研 究は多い. これらの研究に共通するスタンスは, 個別の 事例における現実の豊穣さを活写し，その中から，確か に在ると了解できる有益な知見を得ることを目指すとい うものである ${ }^{12)}$. これは社会学の用語では「厚い記述」 と「解釈による存在了解」と呼ばれる ${ }^{3)}$.

これまでに行われてきた放射性廃棄物処分に関わる紛 争研究は, 大まかに言って 2 通りに分けることができる. ひとつは政策過程分析のように紛争過程のダイナミズム をそのままに記述し，因果関係に基づいて紛争の原因・ 要因を解釈寸る研究 (たとえば本田 (2005) ${ }^{4}$, 石山 (2004) 5), Gamson and Modigliani (1989) $\left.{ }^{6}\right)$ ， もうひとつは，アン ケート調査等に基づく定量的データを統計的に分析する ことにより, 紛争要因を抽出する研究（たとえば Chung and Kim (2009) ${ }^{7}$, Slovic, et al. (1991) ${ }^{8)}$, Kunreuther, et al. $\left.(1990)^{9)}\right)$ である. 本研究では，(対象施設の）特性上事 例数に限界がある高レベル放射性廃棄物処分問題につい て，限られた事例から解決策・緩和策を考案すること， また考案した解決策・緩和策の実施（implementation）に よる影響（実効性）を推定することを目指しているが， 定量的データに基づく統計的要因分析では対象事例の特 
殊性や，考案した対策が実施された場合の影響を考慮す ることは難しい.むしろ, 本研究の目的を達成するには, 具体的な行為・事象・(それらの背景にある) 意図の因果 関係に基づく分析が適している.

そこで本研究は記述的・解釈的なスタンスを踏襲し, まず事例の記述・分析を行った， 新聞各紙 ${ }^{10111)}$, 各種文 献・資料 12)13)14115)16)17およびインタビューによる情報に基 づき，本事例の政治過程を詳細に記述した．インタビュ 一は推進側として前町長, 前町長後援会長 (商工会会長), 町企画商工課長, 反対派として町議, 有力住民（商工会 副会長, 元町議会議長) など, 回数にして 9 回, 11名に 行うことができた. 一回あたりの時間は 1 時間〜2 時間 半であった. また, 現地インタビューに基づく政治過程 記述の後, 処分事業実施主体 (NUMO) に対しても同じ
く 1 時間程度のインタビューを実施した。

次に, 解決困難な対立要因の抽出のため, 本研究では (1)対立要因の抽出, (2)解決策の導出, (3)解決策のシナリ 才分析，という手順を提案する.

まず，過程における各アクターの行動及びその理由か ら過程の推移を決定づけた要因を洗い出し, 因果関係を フロー図に整理，上位の要因となったものを「対立要因」 として抽出した(1). また，その対立要因が，アクターの 心理に影響を与え, 対立につながる心理状態や行動をじ のように引き起こしたかについて記述した，記述の枠組 は, Greenstein and Polsby(1975) $)^{18)}$, 白鳥 $(2001)^{19)}$, Elbing $(1970)^{20)}$ による, 個人の意思決定過程に関する知 見を参考に，以下のように構築した（図1).

政治過程

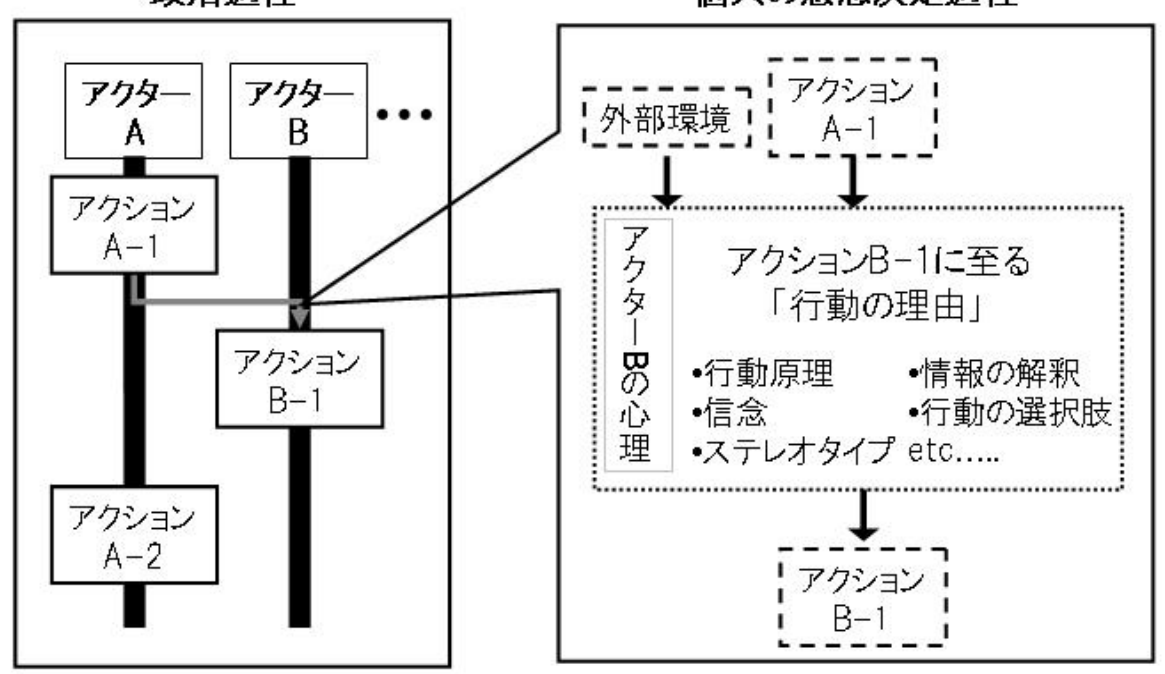

図 1 アクターの意思決定・行動の記述枠組

本研究では, 方法論的精緻さを志向するというよりは, まず政治過程における重要なアクションとその因果関係 を明らかにし，そのアクションが行われることとなった 意志決定における重要な要因を分析することで, 対象政 治過程における本質的な要因と, 解決策の考案・分析に 資する情報を得ることを志向した. 本研究において採用 した記述枠組みは，政策過程内の個々の行動はなぜ行わ

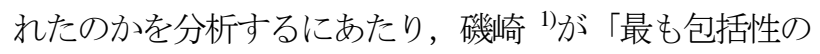
高い」モデル（p.75）として挙げる「動機モデル」と同 様,「行動の理由」(動機モデルでいう動因としての動機, すなわち目的・報酬・主観的期待効用・意識下の動機・ 行動傾向など）には経済的便益の相対的認知や便益の規 模に対する認知，他のアクターから自らの便益がどのよ うに認知されているかに関する認知 (推測) も含めて, 行動の理由となる要因をできるだけ広く分析することを 目的として構築した. 秋吉(2007) ${ }^{21)}$ は行動論的・多元主
義的アプローチの限界を指摘しつつ，アクターの認識枠 組みとその変化を分析する視角として利益・アイディ ア・制度の3つを挙げているが, 本研究における記述枠 組みではこれらの視角（要因）は「行動の理由」に含ま れるものと考えている.

次に, 対立要因を踏まえ, 処分事業実施主体(NUMO) が行える方策を，公募制度の範囲に限定して考案した(2). そして，解決策を対立要因に対して仮想的に導入した場 合，アクターの心理に影響を与え，対立につながる行動 を変化させうるか, 寸なわち対立が緩和ないし解決され うるかを推測した. この推測を本研究ではシナリオ分析 と称した(3).

この手順を踏むことで，公募制度の下で「仮に解決策 が効果を発揮したとしても残る対立要因」を明らかにす ることができる。この残った要因は，公募制度による $\mathrm{HLW}$ 処分地決定プロセスに起因する「解決困難な対立 
要因」の一つといえる.

本研究で提案寸る手法・手順には, 事例の詳細な調査 から知見を抽出する手順を一定程度明確にする意味があ る.これまで行われてきた事例記述・分析に基づく問題 抽出や解決策提案の多く(たとえば Gerrard (1994) ${ }^{22)}$ ) で は, 事例から問題点・解決策を得る手法が必ずしも明確 ではなく, 最終的な知見の抽出は分析者の専門知や経験 に基づく総合的・直観的判断に依拠しているとみられる. これでは, 制度が変更されたり, 異なる政治的・社会的 環境における同様の問題を分析したりする場合, 再度高 い専門性を持つ分析者に頼らざるを得ない. 本研究では, 専門家や経験豊富な者などが，直観によって本質的な知 見を抽出する意義を認めつつも, 本質に辿りつくために より普遍的に利用可能な方法を志向し，上記手法・手順 を提案している.

\section{3. 政治過程の記述（概要）}

まず，本事例の政治過程について概説する. なお，こ の記述は西郷(2009) ${ }^{23)}$ における記述をべースに簡略化し たものである.

2006 年 3 月, 当時の東洋町長・田嶋裕起氏は, 知人の 紹介で NPO 法人「世界エネルギ一開発機構」という団 体と出会う。この団体は, 日本各地に HLW 処分事業を 紹介している団体だという，町長はこの団体から, HLW 処分事業についての概要や交付金の額，応募の方法等を 知らされた. 文献調査に応募するだけで交付金が出るが， 調査後に次のステップに進まなくてもよく, 応募は処分 場の誘致を意味しないことも伝えられた. 町の財政運営 に頭を悩ませていた町長は，ゼロリスクで交付金を受け 取れるいい方法だと考えて応募を即決, NPO の人物に応 募書を託した。

応募書は寸ぐに NUMO に届けられたが，応募が第三 者を介しているため, NUMO は町長に確認の電話を入れ た. その後, 町長, 町役場の企画商工課長, NUMO が話 し合い，応募は町民の理解を得てからにすることとなっ た.

町長は一旦応募についての検討をやめていたが，当時 他の自治体でも応募検討の動きがあったこともあり, や はり貴重な財源になると思い直した. そして7月, 町長 は町議会議員に「HLW 処分事業について勉強する」こ とを提案, 議員も「勉強だけで誘致を論じないなら」と 同意した. 8 月には資源エネルギー庁が交付金の大幅増 額を発表, 町長にはさらに魅力に映った. NUMO と資源 エネルギー庁を招いた非公開の勉強会も行われ，町長之 役場職員, 町議が参加した. 9 月初頭には町長から議員 に対し，今後も勉強を継続すること及び検討しているこ
とを公表・新聞発表することが提案され，了承された.

これにより, 住民も HLW 処分地の文献調査一の応募 が検討されていることを知ることとなった. 少しずつ賛 否の意見が議会等にも届くようになり, 町長は住民を含 めた勉強会を開催することを決めた，勉強会はまずは各 種団体の代表者を対象に開催され, 次いで 10 月には町の 代表的な地区である野根・甲浦両地区で開催された。こ こでは, NUMO や資源エネルギ一庁から処分事業や交付 金についての説明がなされ, 町長も同席した. 勉強会を 経て, 徐々に処分事業への不安を持つ住民, 交付金に期 待して推進の立場をとる住民等が出てきた.

そのころ, 同じ高知県の津野町でも HLW 処分地決定 のための文献調查への応募検討の動きがあったが，町内 外からの反対により,「応募しない」という結論を出して いた. ここで, 津野町で活動していた反対派が, 東洋町 の反対意思をもつ住民と関わりをもつようになった.

そして11月, サーファーを中心とする「生見海岸を愛 寸る全国有志一同」及び，東洋町民や，隣町である徳島 県海陽町民らを中心とする「東洋町を考える会」という 2 つの反対派団体が結成された. その後, 両会と町外の 反対派の協力により, 反対の立場で全国的に活動してい る講師を招いた勉強会が開催された。この勉強会では, 講師から HLW の危険性や応募すると引き返せないとい う見通しが示されたほか, 津野町の反対派からの情報提 供等もあり，住民を驚かせた．この会を境に，反対派の 住民は今後団結して反対運動を行うことを決意した.

12 月, 町長は町内の応募への理解は深まってきたと考 えていた. そこで, 反対派が特に懸念を示していた「応 募すると処分場の立地まで戻れないのではないか」とい う点について NUMO 及び資源エネルギー庁に質問状を 出し，「町長の意思に反して事業は進められない」という 回答を取り付けた上で，応募を前提に議論をす寸めるこ とを町議に提案した. ここで町議たちの賛否は分かれ， 反対意見をもった町議は反対派住民に協力するようにな った.

反対派住民は，文献調査一の応募をしないことを求め る請願署名活動を行っていた. 署名はよく集まり，12月 末時点で 13 歳以上の町民の 6 割に達していた. また, こ の時期以降, 室戸市議会, 徳島県議会など周辺自治体も 反対意思を明らかにするようになった. 東洋町に隣接す る徳島県海陽町では, 住民らによる反対立場での勉強会 も行われた. 海陽町を含む海部郡 3 町は, 町長らが連携 して反対意見を東洋町長に申し入れた.

2007 年 1 月初頭, 立場を明確にしていなかったある町議 A 氏が，賛否を問わず議論することを目的に集会を行っ た. しかし，集まったのは全員が反対派で，署名の数を 根拠に A 町議に反対意思を明確にするよう詰め寄った. これ以来 $\mathrm{A}$ 町議は反対派の急先鋒となるとともに, 議員 


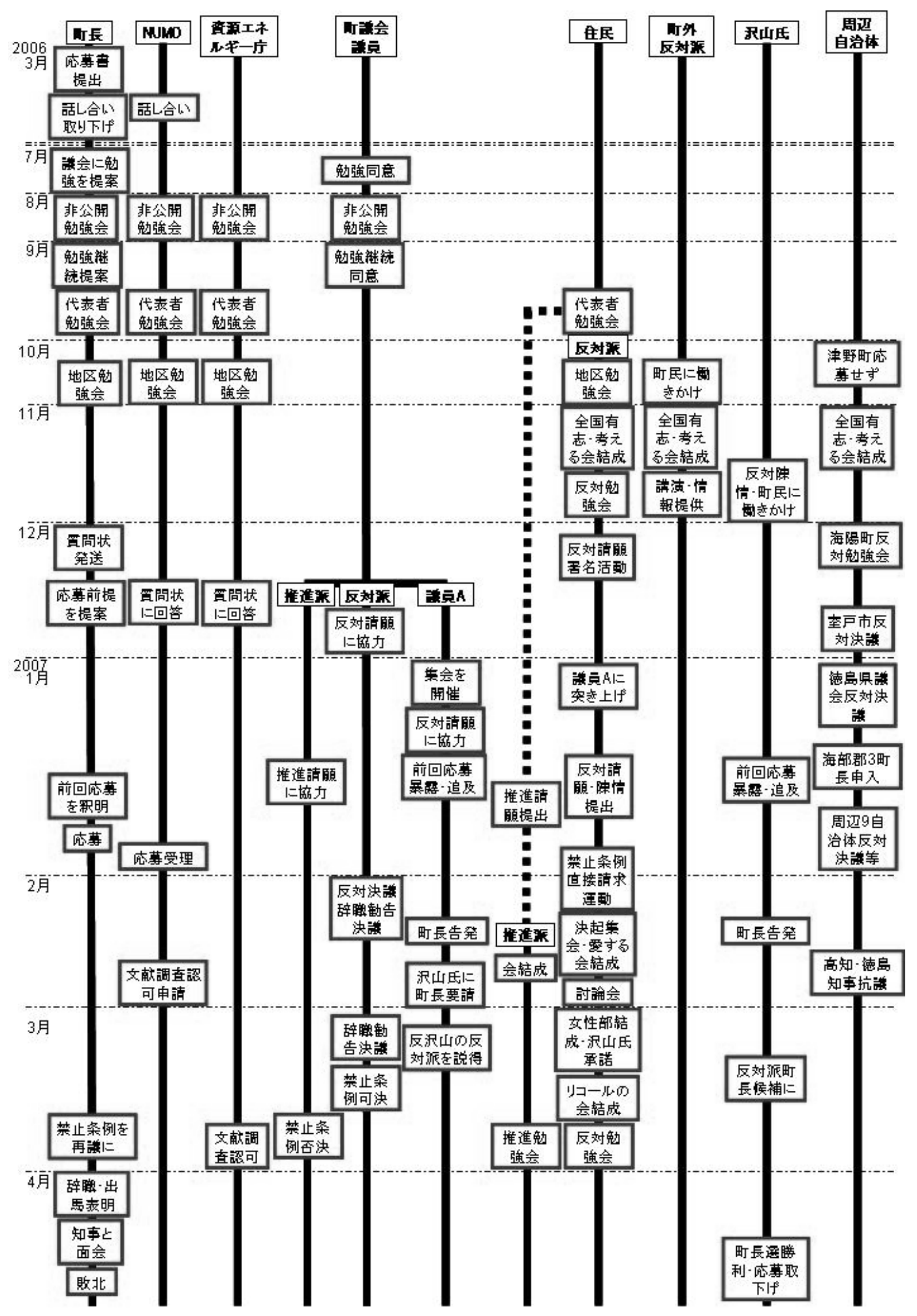

図 2 東洋町の政治過程(概要)

の過半数が反対派となった.

そして 1 月 15 日, 町内 2179 名, 町外 2805 名分の署名 が, 5 名の紹介議員の署名とともに町長に提出されたが, この日, 事態は急展開する. 独自の団体を作って陳情提
出や機関誌発行などの反対運動を展開していた，室戸市 民オンブズマン・沢山保太郎氏が，2006 年 3 月に一旦町 長が書いた応募書のコピーを手に入れ，A町議らととも に町長に迫ったのである. 町長は「軽率のそしりは免れ 
ない」と謝罪したが，これによって「町長はすでに独断 で応募していた」との認識が一般的なものとなり, 町長 の立場は非常に厳しいものとなった. 推進派の住民団体 も署名を提出したが，反対派の署名に比して圧倒的に少 ない，町内 200 名分であった.

そして 25 日, さらに事態は動く. 町長はこの日, 文献 調査への応募を発表したのである. 当時の橋本大二郎高 知県知事は「国・NUMO は応募を受理すべきでない」 釘をさしていたが，NUMO は翌 26 日に応募を受理. 反 対派は国や町長の権力の強さを認識し, さらに反対の意 思を強めることとなった。

反対派は，「核廃棄物持ち込久禁止条例」の制定を目指 し, 直接請求のための署名活動を開始した. 2 月には有 力町民を中心として改めて反対派団体「東洋町の自然を 愛する会」を結成, 町内外の反対派が集まる決起集会が 開かれ，町役場でプラカードや旗を掲げながらシュプレ ヒコールをあげた. 反対派が過半数の議会も, 応募反対 の決議や町長の辞職勧告決議を行った. 高知県・ 徳島県 の両知事や周辺自治体も激しく反対意思を表明した. 沢 山氏と A 町議らが公文

書毀棄罪で町長を刑事告発する動きもあった。一方, 町 長をはじめとする推進派は, 推進派団体「東洋町の明日 を考える会」を結成した.

3 月が近付くと, 町長リコールへの動きが表面化し始 める. 反対派では, リコールした場合の町長候補選びが 難航していた. このころ, 反対派に対する劦しが横行し ていたからである. 紆余曲折を経て, 沢山保太郎氏を候 補とすることとなった. 反対する者も多かったが，「町長 は替えられるが核は一生だ」という認識で沢山氏を支持 した. その際，A町議が沢山氏への要請及ひ擁立のため の反対派内の説得に奔走した.「東洋町の自然を愛寸る会 (女性部)」という団体も結成され, 勉強会やビラ配り等 を行った. この団体も当初は沢山氏擁立に難色を示して いたが，最終的には同意した. 当初から沢山氏を支持し ていた町民グループは「リコールの会」を結成, 反対派 内の対立を残しつつも, 反対運動の中枢となった. 推進 派・反対派はそれぞれ独自に勉強会や討論会を開催，対 立は決定的に深まっていた.

議会では，多数の署名により直接請求された「核廃棄 物持ち込み禁止条例」が一旦可決されたものの, 町長が 条例を再議にかけ，否決に持ち込んだ，その翌日，資源 エネルギー庁は文献調査を認可した。

4 月, 町内は両派の対立や憶測, 劦し等により非常に 混乱していた. 町内の状況を踏まえ, 町長は民意を問う としてリコール成立を待たず自ら辞職, 出直し町長選と なった. 選挙の前には, 橋本知事のたっての希望により, 知事と田嶋氏が面会した. 知事の東洋町到着時には反対 派が旗等を持って歓迎した. そして町長選がスタート,
推進派は田嶋氏，反対派は沢山氏を候補に立て，一騎打 ちとなった. 結果は沢山氏が有権者の約 7 割にあたる 1821 票を得て圧勝, 翌日には沢山新町長が応募を取り下 げた。

以上が東洋町における HLW 処分地決定に係る紛争の 政治過程の概要である. この過程を図 2 にフロー図とし て表現した.

\section{4. 解決困難な対立要因の抽出}

東洋町の政治過程から, 公募制度に基づく HLW 処分 地決定プロセスに起因する解決困難な対立要因の抽出を 行った.

\section{1. 対立要因の抽出}

まず，記述した政治過程におけるアクターの行動とそ の理由のうち, インタビューでの言説や文献等から「激 しい対立」と因果関係を持つと推定できる要因を洗い出 した. さらに要因間の因果関係を整理して上位の要因と なったものを「対立要因」として抽出した. この因果関 係は, 文献やインタビューによって裏付けられたもので ある. 因果関係を示す図を下に示寸 (図3).

整理の結果, 「応募書提出露見」「状況を無視した応募・ 受理」「町主催勉強会」「町外反対派からの働きかけ」「交 付金を用いたまちづくりの訴え」一部推進派の脅し」「レ トリカルな反対宣伝」「地域特有の事情」の 8 つが対立要 因として挙がった.

その対立要因がアクターの心理に影響を与え, 対立に つながる心理状態やアクションを引き起こす様子を, 前 述の図 1 に示した枠組で記述した。例えば「レトリカル な反対主張」について記述したものが図4である. 全国 的に反核運動を行っている町外の反対派が，町内反対派 とともに勉強会を開き，その中で「HLW一本で原爆約 30 発分の放射能があり, それが 4 万本も埋められる」「町 を国に売り渡してはいけない」と, 若干レトリカルとい えるような表現を用いながら講演をした. 参加した町民 はその主張に同意, 対決姿勢で事業に反対するようにな り，反対署名活動を開始. それ以来町側と反対派の話し 合いは不可能となった. そのため, この点は「対立要因」 といえる. ただし，その「対決姿勢」での反対は，基本 的に町を思う素朴な感情に根ざしていることに留意が必 要である. 議員や推進派の有力者等, 各方面から信頼を 得ている有力住民を含めてこの講演での主張が浸透して いたこと等からも，この反対主張に同意した住民は決し て特別な人々ではないといえる.

これらの記述は，すべてインタビューや文献，ブログ 等をもとにしている. 


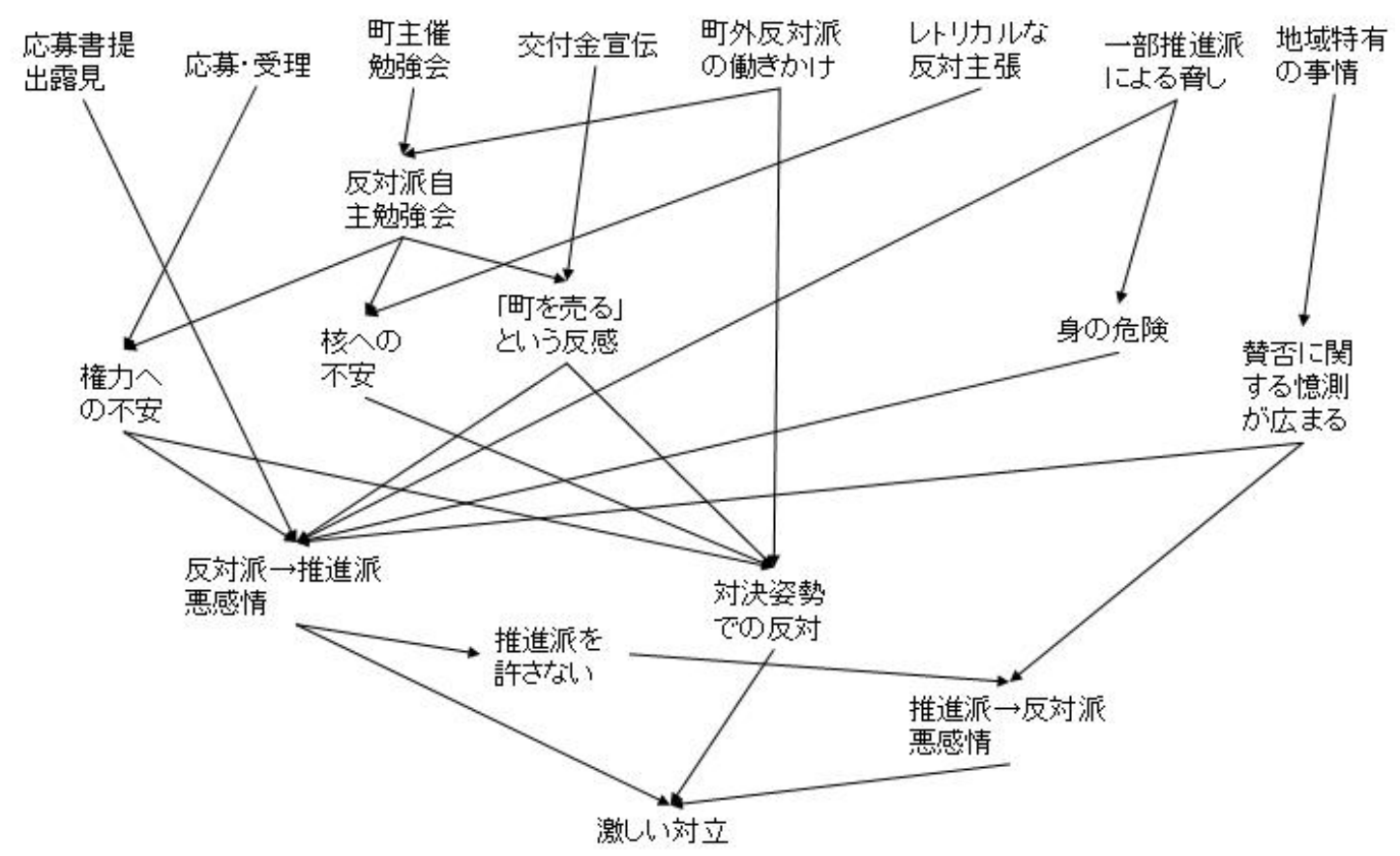

図 3 政治過程において「激しい対立」につながった要因の因果関係

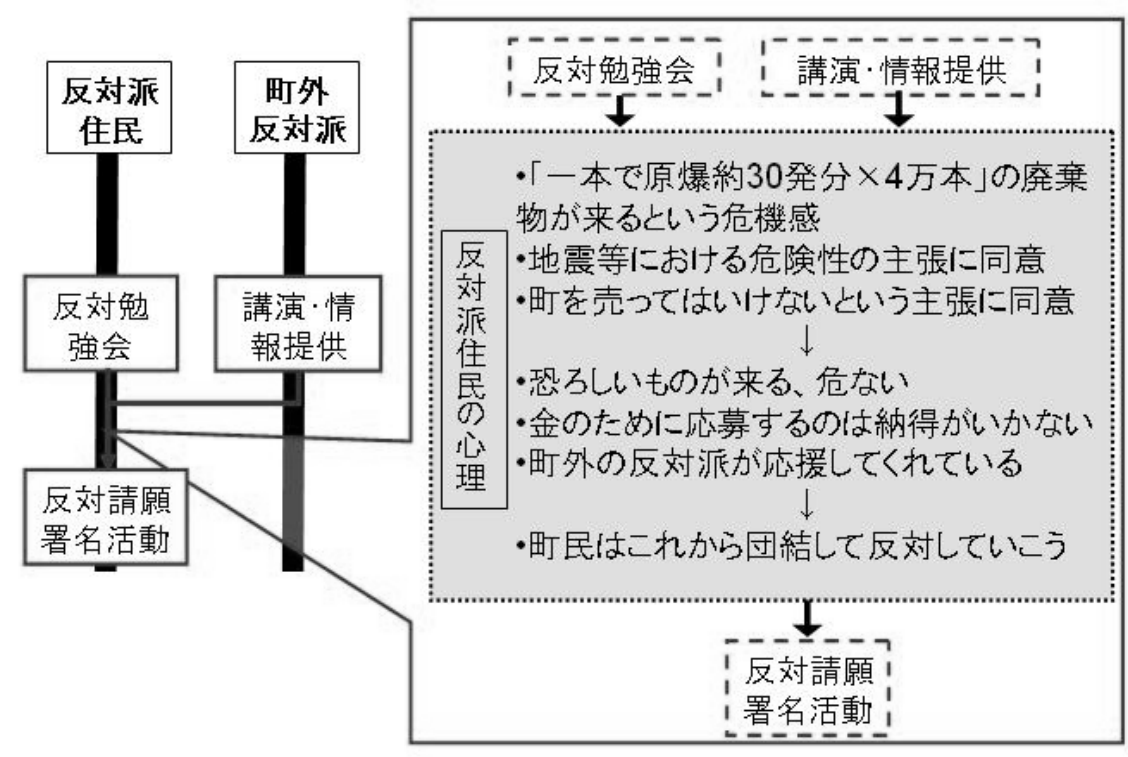

図 4 対立要因の例(レトリカルな反対主張)

また「応募書提出露見」および「状況を無視した応募・ 受理」について記述したものが図 5 である. 2006年3月 の応募書提出について自ら言及せず, 2007 年 1 月に沢山 氏によって暴露されたことで, 町長は信頼を大幅に失い, 町内は混乱した. その混乱や多くの反対がある状況の中 町長が文献調査に応募したことで, 反対派は町長の権力 の強さを意識し, 不安を覚えた. さらにその応募が受理 されたことで, 反対派は立地プロセスが地元の反対を押
し切って進んでいくという不安を覚えた. よって, 反対 派は「核廃棄物持ち込み禁止条例」の直接請求というよ り拒否色の強い反対手段をとるとともに，リコールの検 討に入った.ただし，この段階ではまだ町長の翻意に期 待していたため, 条例の直接請求にとどめていた. 以上 のように，「応募書提出露見」および「状況を無視した応 募・受理」は対立をより深める原因となったと考えられ るので,「対立要因」であるといえる. 


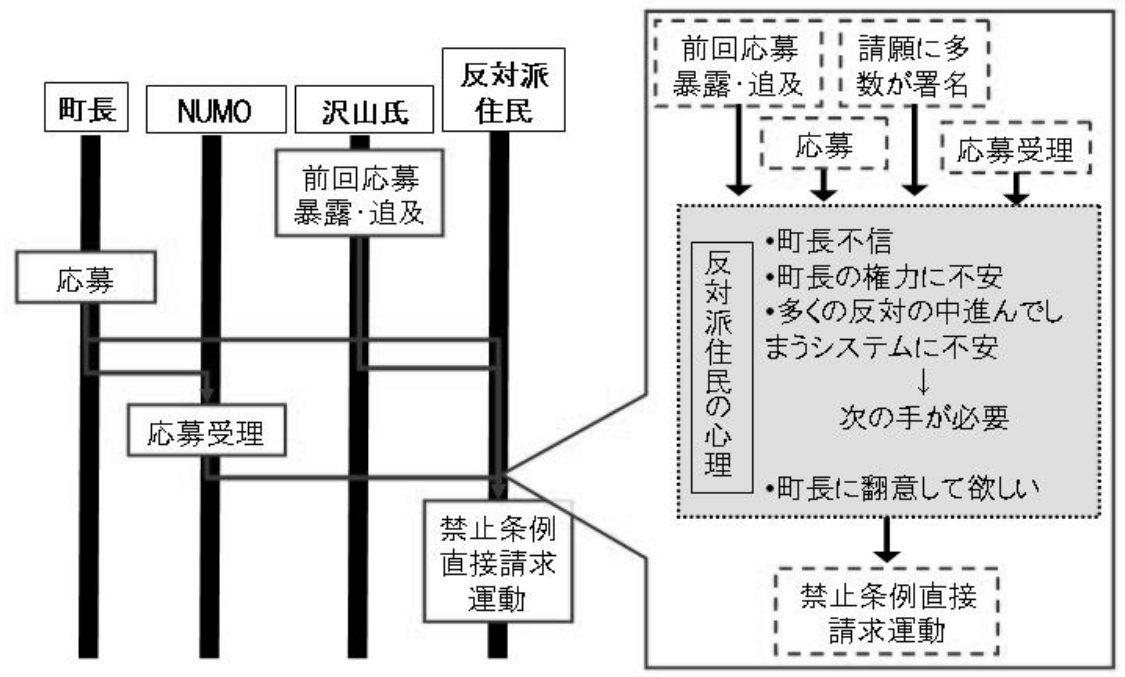

図 5 対立要因の例(応募書提出露見, 状況を無視した応募・受理)

\section{2. 解決策の導出 ・ シナリオ分析}

続いて，解決策の導出及びシナリオ分析を行った. 本研究における解決策の導出は, その解決策によって 実際に課題を解決することよりも，解決策についてシナ リオ分析を行うことで, (公募) 制度に起因する解決困難 な対立要因を探ることに主眼がある，そのため，ここで は, 対立要因「応募提出露見」及び「応募・受理」に対 して「理解が得られてから応募する」, 対立要因「一部推 進派の劦し」に対して「一部推進派の脅しを防止する」 といった，当然といえる解決策については検討しない． また，対立要因「地域特有の事情」に対して「地域対立 に配慮する」という解決策については，HLW 立地プロ セス外の条件の影響が大きいため,ここでは検討しない， 残る 4 つの対立要因に対し, 以下の 4 つの解決策を考案 した.

1. 町外から反対派が来てこのような主張をする，と事 前に根回しする

対立要因「町外反対派の働きかけ」「レトリカルな反対 主張」に対応する.

2. 技術的問題に第三者からの意見を加える

対立要因「町主催勉強会」「町外反対派の働きかけ」「レ トリカルな反対主張」に対応する.

3. 交付金ではなく, 国にとっての原子力の必要性と国 の重要政策を担う矝持を前面に押し出して理解深耕 をはかる

対立要因「町主催勉強会」「町外反対派の働きかけ」「交 付金宣伝」に対応する.

4.レトリカルな反対主張に積極的に反論する 対立要因「レトリカルな反対主張」に対応寸る.

これらの解決策がアクターの心理に影響を与え，心理
状態やアクションを変化させる可能性について記述した. ここでは，制度に起因する解決困難な対立要因を探る ことを主眼とし，解決策が効果を発揮すると仮定してい る. すなわち，ここで提示するシナリオは他の考えうる シナリオに比して起こりやすいとはいえず，むしろ解決 策の効果についてあえて楽観的に想定している. 本研究 では，楽観的な想定にもかかわらず，対立を解消できな いと考えられる対立要因を「制度に起因する解決困難な 対立要因」としている.

例えば, 対立要因「レトリカルな反対主張」に対して, 解決策「事前の根回し」, 寸なわち町外反対派のレトリカ ルな主張が行われる前に根回しが行われ，それが効果を 発揮した場合, 東洋町の状況が変化しうるかを以下のよ うなシナリオとして推測した.

X 町およびNUMO では, X 町が HLW 処分のための文 献調査に応募するかどうかを検討するため, 勉強を進め ることとなった. 町長・役場の主要職員・町議会議員の 中では, 賛否は分かれるものの, 勉強を進めること自体 について異論はなかった。

ここで，東洋町での紛争を踏まえると，この検討につ いて公表すると，町外から反対派がやってきて，町内の 反対意識を持つ町民と結びつき, 反対運動が激化して話 し合いが進められなくなってしまうことや，反対意見を 持つ住民に対して過激な推進派から劦し等の行為が行わ れてしまうことが予想される. そこでNUMO は，推進・ 反対どちらの結論が導かれるとしても, それが冷静な議 論によって行われるために, 公表前に, X町各地区の信 頼を得ている有力者に対し, 以下 2 点を根回しすること とする.

・賛否の結論を泠静に出すための勉強を進めていく 


$$
\text { こと }
$$

- 今後, 町外から過激な推進派・反対派がやってきて 運動を激化させようとするが, 町内が混乱するため, 冷静に対処してほしいこと

すなわち，町民が推進・反対運動をしないよう押さえ 込むのではなく，あくまで「過激分子」の働きかけに注 意するようにという根回しである.

各有力者にも賛否両論があったが，時間をかけて根回 しし, 勉強するという点では同意を得た. その後, 各有 力者を経て, 住民に根回しの内容が浸透したのち, 検討 を行っていることを公表するとともに，住民説明会等の 勉強活動を開始した. 勉強会においては, 現在の地層処 分技術の現状や，交付金制度，事業による経済効果，事 業の意義等が説明される.

住民説明会を経て，住民は賛否両論となる，一部の有 力な反対派住民に対して劦しがかけられるが，事前にそ の可能性を予見していたため, 警察・町等とともに冷静 に対処できる。

また，反対意見を持つ住民に対し，町外反対派がアプ ローチ寸るようになる. 町外反対派によって, 核の恐ろ しさ・安全性への疑い等が扇情的に伝えられるが，事前 にその可能性を予見し，正確な情報が伝えられていたた め, その主張を一方的に信じることはない.

しかし, 町内・町外反対派による「なぜこの町が応募 しなければならないのか, 金のために応募するのか」と いう批判については, 事実経済効果を見込んでいる推進 側から反論ができない，経済効果を見込んでいることを 直接に主張することは, 反対感情の原因を取り除くよう な「反論」ではなく, 反対感情の存在を是認する「開き 直り」となってしまうのである. そのため, 結局町内の 反対派は推進を含めて議論することに納得がいかず, 団 結して反対運動を開始することとなる.

以上のように,たとえ事前に根回しを行ったとしても， 事業者側・推進側が「金のための応募」という批判に反 論できないことが対立の解消を妨げ，対立は解決されな いと推測した.

以上のシナリオを図化したものが図6である.

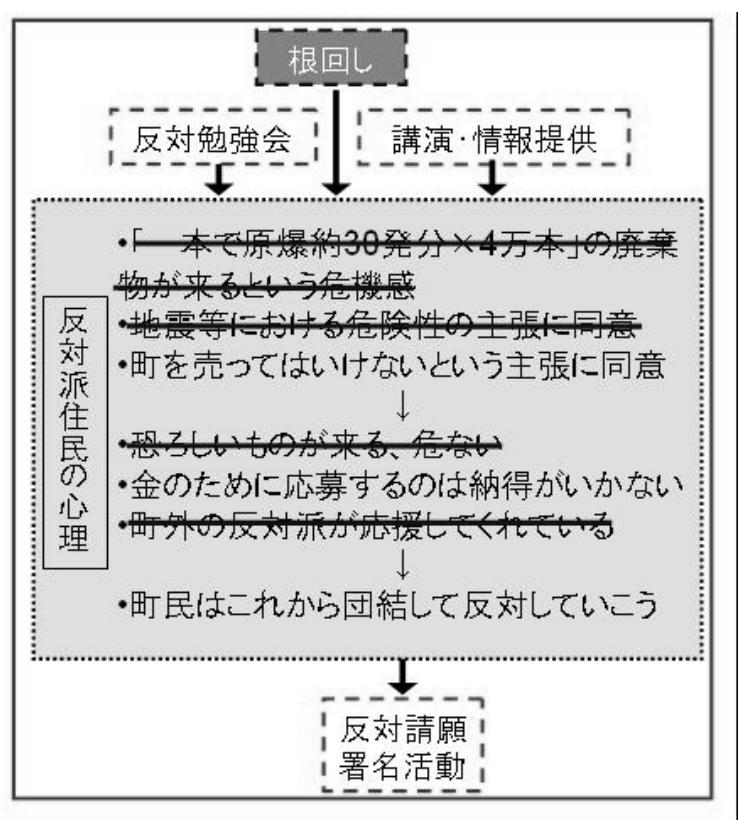

図 6 シナリオ分析の例(事前の根回し)

また，対立要因「交付金宣伝」に対して解決策「国の 政策を担う誇りを押し出した理解深耕」,すなわち金に関 寸る批判に対して，交付金ではなく国の重要政策のため に事業を行うという矝持を押し出して理解深耕をはから た場合について,以下のようなシナリオとして推測した. 東洋町では，推進派が交付金等を売りにして応募を訴 えたため,「金のために応募している」「交付金漬けにな る」との批判に反論できない. そのため反対派は推進派 に歩み寄る理由がなく，対立が激化したと考えられる. 当時の橋本知事も「(国は)札束で(地方の)煩を吒くな」と 積極的に批判していたほか, 交付金の額が東洋町での検 討が本格化する直前に大幅増額されるという, 「国は金で 東洋町を狙いうちしているではないか」という憶測を呼 ぶ状況もあった. また, 交付金が落ち始めると推進派が 増える, 反対派からみると「買収」されるのではないか という危機感もあった.

そこで NUMO は，交付金ではなく「国の原子力政策 を担うという誇り」を前面に出して応募への理解を求め ることとする. この立場では, 当時の橋本知事の立場と 相容れないものではなく, 当然ながら交付金の増額等も 行われない.

住民説明会等では，交付金とそれを活用した事業につ いては「あくまで処分事業を行った結果であり, 交付金 そのものが目的ではないとと立場から形式的な説明に とどめ, 処分事業の意義について中心的に説明する. 住 民は賛否両論となったが, 反対派となった住民も, 総論 としての処分事業の意義については納得を得られる.

しかし，「なぜこの町が自ら応募するのか」という点に ついては, 国の重要政策であるというだけでは納得でき 
ない，それにも関わらず自ら応募するのは，自分たちの ような貧しい田舎が交付金メリットを享受するためでは ないかという推測が容易に成り立つ。ここから, やはり 施設が危険であるから都会を避けている，という推測に も到達する. そのため, 町外反対派らの「金のために町 を売るのか」という扇情的な訴えに共感するとともに, この先「買収」によって推進派が増えるのではないかと いう危機感を覚え，結局対立が激化する.

以上のように，たとえ推進派が交付金メリットを強調 しないようにしたとしても, 自ら応募して交付金を受け 取るという構図自体は変化しないため, 批判は残ると考 えた.

以上のシナリオを図化したものが図 7 である.

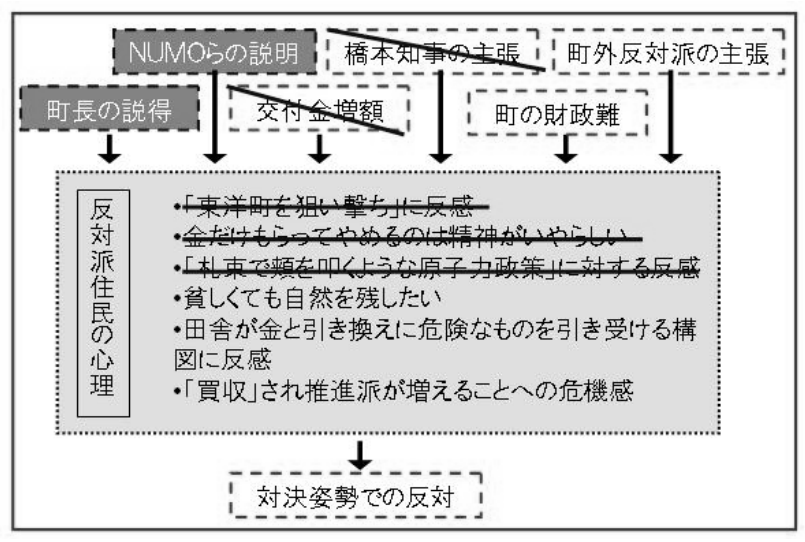

図 7 シナリオ分析の例（国の政策を担う誇りを押し出した理 解深耕)

他の解決策についても同様の分析を行ったところ，技 術的な問題に第三者の意見を加える，レトリカルな主張 に積極的に反論を加える, の両策については, 効果を発 揮するという仮定のもとでは対立要因は残らないと考え られた。

以上より，公募制度には「自ら応募し，交付金を受け 取るという構図」の存在により，金目当ての応募である という批判に反論できないという, 制度そのものに起因 する解決の難しい対立要因が存在する可能性が否定でき ないという結論を得た. 仮に上記の解決策が完全に機能 したとすると，推進・反対双方の意見がそれなりの根拠 があると受け止められ，住民がレトリカルな反対主張に 一方的に流されることもなくなるであろう. しかしなが ら, 「応募すると交付金が下りる」という構図がある限り， 「反感の根が残り，感情的な対立を招くおそれがある.

すなわち, 公募方式のみによる HLW 処分地決定プロ セスには解決困難な対立要因がつきまとうことが本研究 から示唆できたといえる.

\section{HLW 処分地決定プロセスへの示唆}

\section{1. 申し入れ方式に関する考察}

本稿では公募方式のみによる処分地決定プロセスには 解決困難な対立要因がつきまとうことを示唆したが，公 募方式ではなく, 申し入れ方式にした場合, 対立は解決 されるといえるのだろうか. ここでは, 2009 年現在の HLW 処分場立地プロセスが「公募方式と申し入れ方式 の併用」となっていることから, 申し入れ方式によるプ ロセスに関しても本事例をもとに簡単に考察する.

まず，本研究で解決困難な対立要因として挙げた，金 目当ての応募であるという批判に反論できないという点 については，国から申し入れを受けた自治体が同様の批 判を受けた場合,「国から言われて仕方なく受け入れた」 と反論することが可能となる，これにより，自治体側は 後ろ暗い所がなくなり, 筋の通った主張ができるように なり, 反対派との議論は「国から札束で㚘を叨かれるこ とを認めるか否か」から，「国の政策を受け入れることを 認めるか否か、に移行寸ると考えられる.この移行は感 情的対立の緩和に資寸るものであると推測される.

また，本事例においては，東洋町長による応募の動き に対して橋本知事が強い反対を表明し続けたが，申し入 れ方式においては知事の頭越しでの申し入れは考えられ ず，知事と首長の間で激しい対立が起こることはなくな る可能性がある.

全体として公募方式と申し入れ方式でそれぞれ起こる 反対の構図の違いとしては, 公募方式においては本事例 のように国(NUMO を含む)と首長の双方, 特に首長に対 する反対となるのに対し, 申し入れ方式では主に国に対 する反対という形になると考えられる.この国に対する 反対は, 公募方式にもまして激しいものになる可能性が 高い. 本事例においても, 国・NUMOに「強権性」を感 じた反対派は多かった. 改革で地方を弱らせ, 危険施設 を受け入れざるを得ない状態にしている」という批判も 広く受け入れられていた. 比較的穏健な反対派でも, 成 田空港をはじめとするかつて国が強権的に行った事業を 想起していた. 反対運動に便乗して政治的主張を行う向 きも見られた. 申し入れ方式は，より「強権性」が際立つ 制度であり, 進め方によっては, 上に挙げたような火種 は公募方式以上に激しく燃えることになる. 寸なわち， 「成田」のような, 反対運動の全国的な広がり・政治団 体の便乗・武力闘争の危険性まで想定される. その進め 方は, 本事例を含む事例研究等を踏まえ, 慎重に検討さ れなければならない。

\section{2. 事業者によるシナリオ分析の利用の可能性}

HLW 処分地決定プロセスに関して本研究が示唆でき るいま一つの点として, 事業者(NUMO)がシナリオ分析 
を利用して事業の進め方を改善できる可能性が挙げられ る. 本研究では, 様々な解決策が機能したと仮定しても 残る「解決困難な対立要因」を抽出するための手段とし てシナリオ分析を用いたが，ここでは，事業者があるア クションを起こしたときの各アクターへの影響予測をす ることを想定する.

本研究で紹介したシナリオ分析は, あるアクションが 他のアクターにどのような影響を与えるかを, 過去の事 例における特定のアクション・イベントによる影響や, たとえば Theory of Reasoned Action (Fishbein 1967"24); Fishbein and Ajzen 1975 25 ) や Theory of Planned Behavior (Ajzen 1985) ${ }^{26)}$ といった理論をもとに予測する際に, 枠組 として用いると有効である. 事業者が自らの行動を決定 する際, シナリオ分析を経ることによって，その行動を 他のアクターにとってもよりよいものにできる可能性が ある. 寸なわち, 事業者の現地対応が改善できる可能性 がある.

\section{6. 発展}

ここでは，本事例から得られた示唆から，今後より深 い研究が期待される点について述べる.

\section{1. 交付金に対する認識の国・地域による差異}

本研究では，「金」に対寸る反感を解決困難な対立要因 として提示した. 実際に, 当時の橋本知事の発言「札束 で㚘を吒くな」は注目を集め, 反対派の勢いを増す効果 を持っていた. 知事が東洋町を訪れた際, 出迎えた反対 派住民が持つプラカードで最も大きかったものには「金 と引き換えの放射能は要らない!」と大書きされていた. 交付金だけを手にいれ，いざ処分場を造るとなったら手 を引こうという意見(制度上は可能である)に対しては， 「手を引かせてくれるとは思えないという意見のほか， 「金だけをもらって手を引くのは精神がいやらしい」と いう意見が共感を得ていた，我が国においては，このよ うに交付金を受け取ることを悪いことととらえる意見は 比較的共感を得やすいと思われる.

しかし，世界的にはこの認識は必ずしも一般的ではな

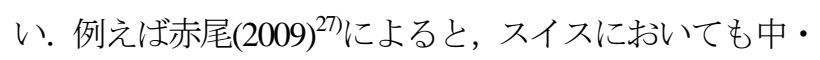
低レベル放射性廃棄物処分場に対寸る反対運動があった が，住民の意識は交付金への反感よりもむしろ選定プロ セスへの反感にあった. また, Chung and Kim (2009) † おいて分析されている韓国の事例では, 明確な経済的义 リットはむしろ処分場の受容にとって重要な要素として 挙げられており, 交付金受領といら行為は「後ろめたい」 もの（あるいは「悪」そのもの）としては捉えられてい ない. 同様に, 現在筆者らが現地調查等を進めるフラン
ス・ビュールにおける HLW 処分地下研究所立地の事例 においても，交付金受領に対してネガティブな感情を持 っていたり，外部の者が反感を抱いたりしているといっ た話は聞かれず，むしろ当然の代価であるという認識を 持っていると思われる.

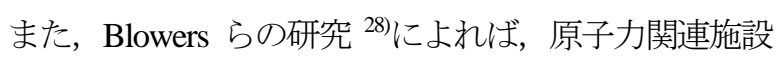
がすでに立地している地域・自治体 (”Nuclear Oasis”) は, 原子力に関する知識量や交付金一の依存体質, 実施主体 と自治体との間にある権力の不均衡などの要因から, 放 射性廃棄物処分場を含む新たな原子力関連施設の受け入 れに拒否反応を示しにくい特性を持っている. 韓国の事 例 7でもすでに月城原子力発電所の立地する慶州ではリ スク認知が低く, 経済的便益に対寸る認識が非常に高か ったといった要因が，中低レベル放射性廃棄物処分場の 受け入れに一定の影響を及ぼしていた。 このように，原 子力関連施設既存地域においては, 必ずしも交付金の存 在が住民に反感を持たれるわけではなく, むしろ冷静に 交付金に関する交渉・判断といったアクションに至る可 能性がある.

このような，交付金に対する認識の国・地域による違 い, あるいは立地する施設による違いについて, その違 いが生じる背景を含めて分析することは, 今後の迷惑施 設の立地問題の緩和に資すると期待される. さらに, 経 済的便益の配分方法（フランスの GIP, 韓国の各住民一 の交付金配布，日本の電源三法交付金制度など）や，住 民ごとの経済的便益に対する規模感といった要因の影響 も, 今後の研究において分析される必要があると考えら れる.

\section{2. 住民参加の形式 - タイミングに関する分析}

本事例では，まず住民の間に処分場に対する反対の気 持ちが沸き起こり，その気持ちを表現する手段として， 請願署名や直接請求，リコールといった住民参加の手続 きがとられていた，我が国においてはこのように，住民 参加の手続きが「反対」のために使われるケースが多い.

しかしこれも必ずしも一般的にいえることではない． 韓国では, 2003 年から 2004 年にかけて扶安郡ウィドに おいて発生した紛争で自主的な住民投票によって反対意 思を表明するという, 東洋町の事例に酷似したケースが あった．ところが，同時期に住民投票法が制定され，放 射性廃棄物処分地選定制度においても住民投票という手 続きによって意思決定を行うよう方針が転換されると, 4 自治体が中低レベル放射性廃棄物 (LILW) 処分地に立候 補し，その全自治体で賛成率が 6 割を超えるという結果 となった (うち, 賛成率 $89.5 \%$ の慶州市に決定).もち万 ん, 前述の Chung and Kim (2009)の論文で示されているよ うに, 扶安郡ウィドのケースとは異なり, 住民投票法成 立だけでなく, HLW の切り離し, LILW 処分施設誘致地 
域支援特別法制定（これによる補助金の確約）など，処 分地一の立候補や賛成率上昇を決定づけた重要要因があ ったことは事実であろう。しかしながら，推進・反対と 完全に色分けがなされる以前の段階から住民が参加でき, 話し合える枠組みがあれば，その後の先鋭的な対立を予 防できる可能性がある. また, 住民投票が反対意思の表 明手段として捉えられるのではなく, はじめから意思決 定手段として処分地選定制度にビルトインされているこ とは，先鋭的な反対が卓越する可能性を減じるのではな いかとも考えられる. このような，住民投票（住民の意 思決定手段）や住民が議論に参加する形式やタイミング に関する分析が，各国の事例からなされることが期待さ れる.

以上のような他事例との比較等による知見（特に紛争 の結果を決定づけた要因に関する知見)の体系化のほか, 放射性廃棄物処分制度や処分地選定に関わる紛争につい ての分析を通じた, 関係する価值・規範の整理といった 規範的研究も, 放射性廃棄物処分を考える上では必要な 基盤的研究といえるだろう. 本研究では, HLW 処分場 立地地域選定に関わる文献調査一の応募によって生じる 住民間の紛争や禍根を解決すべき問題としてとらえ, そ の解決に資する基礎的情報として東洋町における政治過 程を分析し, 対立要因を示した. しかし, 東洋町におけ る調査でも言説として得られていたが，そもそも放射性 廃棄物処分事業や原子力利用についての納得が得られて いないことが，住民の不信・不満・反感につながってい たことは事実であろう。この点を鑑夕ても，放射性廃棄 物の「排出者責任」や原子力利用と関わる「経済発展」,

「環境保護」さらには都市と地方の「公平性」などいっ た複数の価值・規範に関して, 規範的研究が行われるこ とは重要であると考えている.

また，当然ながら，本研究の不十分な部分について， 本事例に対してより詳細かつ多角的な視点で迫ることも 可能である. 例えば，本研究においては「解決困難な対 立要因」の抽出の道具として「解决策」を用いたが，こ の HLW 処分の問題においては, 本来的には「解決策」 を精緻化し，事業の進め方を具体的にどのようにすべき か，という点が求められているところである. 各解決策 をとった場合の各アクターの動きについてより詳細に分 析し, 各解決策の効力を示寸など, さらに HLW 処分問 題の解決に踏み込んだ研究も必要となろう。

そのほか, 本研究では住民・関係者に対するインタビ ユー調査および文献調査によって基礎的データを得たが, こうした手法の選択によって住民が潜在的に有する利得 構造や，あえて公式には表明することのない交付金への 関心などといった要因が適切に評価されていない可能性 は否定できない. アクターの意志決定過程記述枠組みで も，アクターの行動がなぜ行われたのかという点に注目
したため,「行動の理由」とまとめられる要素, たとえば 規範が政治過程の中で「変化した」ということが重要な 要因であった場合, これを十分評価できない恐れもある. 今後, 東洋町の事例を用いて他の手法による分析を実施 することで, 多角的に事例を検討し, その上で改めて本 事例における政治過程・意志決定に強く影響を与えた重 要な要因を整理し直すことが必要であろう。このような 多角的な分析を複数の事例において実施することを通じ て, 放射性廃棄物処分事業における制度的な対立要因分 析枠組みや，住民の態度形成分析枠組みなどを方法論化 していくことが今後の課題である.

\section{参考文献}

1) 磯崎育男(1997) 『政策過程の理論と実際』芦書房.

2) 早川洋行(2007)『ドラマとしての住民運動 社会学者がみ た栗東産廃処分場問題』社会評論社

3) 今田高俊(編)(2000)『社会学研究法 リアリティの捉え方』 有斐閣.

4) 本田宏（2005）「脱原子力の運動と政治一日本のエネルギ 一政策の転換梳可能加」北海道大学図書刊行会.

5）石山徳子（2004）「米国先住民族と核廃棄物一環境正義を めぐる闘争一」明石書店.

6) Gamson, W.A. and Modigliani, A. (1989). Media discourse and public opinion on nuclear power: A constructionist approach. The American Journal of Sociology, 95(1), 1-37.

7) Chung, J.B. and Kim, H.K. (2009). Competition, economic benefits, trust, and risk perception in siting a potentially hazardous facility. Landscape and Urban Planning, 91, 8-16.

8) Slovic, P., et al. (1991). Perceived risk, stigma, and potential economic impacts of a high-level nuclear waste repository in Nevada. Risk Analysis, 11(4), 683-696.

9) Kunreuther, H., et al. (1990). Public attitudes toward siting a high-level nuclear waste repository in Nevada. Risk Analysis, 10(4), 469-484.

10) 高知新聞 2006 年 8 月 6 日付以降.

11) 朝日新聞 2006 年 9 月 14 日付以降.

12）原田英祐(2007)『東洋町歴史年表・改訂版』自費出版.

13) 田嶋裕起(2008)『誰も知らなかった小さな町の原子力戦 争』ワック出版.

14）まさのあつこ(2007)「それは，闇』社会からもたらされ た一高知県東洋町『放射性廃裹物処分地』騒動記』『論座』 2007 年 8 月号, 164-169.

15）東洋町企画商工課(2007)『「高レベル放射性廃棄物の最終 処分施設設置可能性を調查」することに関する経過報告 書』東洋町役場.

16) noe (2007)『美は乱調にあり 諧調は偽りなり』 
http://noe.mo-blog.jp/weblog/ [2009, September 13].

17) 原発さよならネットワーク高知(2006)『それがたまる か！！』 http://geki1015.cocolog-nifty.com/blog/ [2009, September 13].

18) Greenstein, F.I. and Polsby, N.W.. (1975). Micropolitical theory. Addison-Wesley series in political science; Handbook of political science ; v. 2. Reading, MA: Addison-Wesley Publishing Company.

19) 白鳥令(2001)『政策決定の理論』東海大学出版会.

20) Elbing, A.O. (1970). Behavioral Decisions in Organizations. Glenview, IL: Scott, Foresman and Co.

21) 秋吉貴雄 (2007) 『公共政策の変容と政策科学』有斐閣.

22) Gerrard, M.B. (1994). Whose Backyard, Whose Risk: Fear and Fairness in Toxic and Nuclear Waste Siting. Cambridge, MA: The MIT Press.

23) 西郷貴洋(2009)『高知県東洋町における高レベル放射性廃 棄物処分地決定に係る紛争の政治過程分析』東京大学大 学院工学系研究科修士論文.

24) Fishbein, M. (1967). Attitude and the prediction of behavior. In Fishbein, M. (Ed.) Readings in attitude theory and measurement. New York: Wiley.

25) Fishbein, M. and Ajzen, I. (1975). Belief, attitude, intention, and behavior: An introduction to theory and research. Reading, MA: Addison-Wesley.

26) Ajzen, I. (1985). From intentions to actions: A theory of planned behavior. In Kuhl, J. and Beckmann, J. (Eds.) Action control: From cognition to behavior. New York: Springer-Verlag.

27) 赤尾宣長(2009)『スイス・ヴェレンベルグにおける低・中 レベル放射性廃棄物処分場における住民の態度形成の分 析』東京大学大学院工学系研究科修士論文.

28) Blowers, A., Lowry, D. and Solomon, B.D. (1991). The International politics of nuclear waste. London: Macmillan.

\section{謝辞}

高知県・東洋町でのインタビュ一開始にあたり多大な ご協力をいただいた高知県議会議員・植田壮一郎氏，ま た，長時間にわたるインタビューにご協力をいただいた 東洋町及び室戸市の皆様に深く感謝申し上げる. インタ ビューに同行いただいた高知工科大学・中川善典講師ご 夫妻にも併せて感謝申し上げる.

本研究は科研費・基盤研究（B）（課題番号 21360465） の助成を受けたものである.

\title{
DECISIVE FACTORS OF THE DISPUTE REGARDING HIGH-LEVEL RADIOACTIVE WASTE REPOSITORY SITING AT TOYO-CHO, KOCHI, JAPAN: AN ANALYSIS OF POLITICAL PROCESS AND POSSIBLE SOLUTIONS
}

\author{
Takahiro SAIGO ${ }^{1}$, Shunsaku KOMATSUZAKI ${ }^{2}$, and Hideyuki HORII ${ }^{3}$ \\ ${ }^{1}$ Ms.Eng., Mitsubishi Research Institute, INC., Science and Safety Policy Research Division \\ (E-mail: saigo@mri.co.jp) \\ ${ }^{2}$ M.A. (Political Science) Research Fellow, Graduate School of Engineering, The University of Tokyo \\ (E-mail: komatsuzaki@civil.t.u-tokyo.ac.jp) \\ ${ }^{3}$ Ph.D. (Sociotechnology), Professor, Graduate School of Engineering, The University of Tokyo \\ (E-mail: horii@civil.t.u-tokyo.co.jp)
}

\begin{abstract}
Between 2006 and 2007, Toyo-cho, Kochi experienced a serious antagonism among citizens caused by the dispute regarding the decision making of high-level radioactive waste (HLW) repository siting. In order to avoid such an antagonism in future candidate municipalities, decisive factor(s) of the dispute, especially unavoidable one(s) under the "voluntary-base" siting policy, must be analyzed. Based on our political process analysis, causal analysis and scenario analysis, it has been found that the "voluntary-base" siting policy cannot avoid the decisive factor that a voluntary application disables an applicant municipality from refuting the opposing movement criticizing "application for money".
\end{abstract}

Key Words: High-level radioactive waste repository siting, political process, scenario analysis, decisive factors of dispute, Toyo-cho, Kochi 